\title{
Shoot population dynamics of beaked sedge following cattle grazing
}

\author{
DOUGLAS R. ALLEN AND CLAYTON B. MARLOW
}

\begin{abstract}
Authors are range ecologist, Spokane County Conservation District, N. 222 Havana, Spokane, Wash. 99202; and associate dean, Resident Instruction, College of Agriculture; and associate professor, Department of Animal and Range Sciences, Montana State University, Bozeman 59717.
\end{abstract}

\begin{abstract}
We studied the effect of cattle grazing on shoot density and flux in 4 southwest Montana beaked sedge (Carex rostrata ex With.) stands for 2 years. Forty plots were protected and $\mathbf{4 0}$ plots were grazed by cattle in June and September of 1989 and 1990. The effect of grazing vs. no grazing on mean shoot density and emergence varied over time (treatment by time interaction $P<0.001$ and $P=0.003$, respectively). About $90 \%$ of the time by treatment interaction for shoot density occurred from September 1989 through July 1990. Mean shoot density increased more in grazed plots than in ungrazed plots in spring 1990, and remained 12-16\% higher during the last 6 months of the study. Mean shoot emergence was $20 \%$ greater $(P=0.006)$ in the grazed than in the ungrazed plots, with the greatest monthly differences occurring after 3 of the 4 grazing treatments. Mean shoot height declined similarly from June 1989 to June 1990 in the grazed and ungrazed plots (6 and 5\%, respectively), indicating that productivity per shoot was similar between treatments. Beaked sedge in our study site was tolerant of light to moderate grazing, given adequate regrowth between spring and fall treatments.
\end{abstract}

Key Words: beaked sedge (Carex rostrata), population dynamics, grazing compensation, riparian grazing

Riparian plant communities comprise only 1 to $2 \%$ of the total land area of the western United States, but provide a disproportionately greater amount of cover and forage for wildlife and livestock (Tiner 1984, US Government Accounting Office 1988). Before grazing management guidelines can be developed for riparian sites, grazing response of riparian species must be understood. Maschinski and Whitham (1989) suggested that grazed plants respond along a continuum (from undercompensation to overcompensation), depending on many factors such as type of tissue grazed, plant species, nutrient and water availability, and grazing management. There is little information regarding the position of riparian graminoids along the compensation continuum.

Beaked sedge (Carex rostrata Stokes ex With.) has a circumpolar distribution in temperate climates and is a dominant herbaceous component of hydric riparian communities in the northern Rocky Mountains (Kovalchik 1987, Hansen et al. 1988). Although beaked sedge is thought to be moderately palatable to cattle and moderately tolerant of grazing (Hermann 1970, Ratliff 1983) the species may be replaced by other riparian graminoids when heavily grazed over extended periods (Kovalchik 1987).

Beaked sedge is strongly rhizomatous (Bernard and Gorham 1978), which allows for translocation of nutrients and water

This research was funded by the Montana Agricultural Experiment Station. The authors wish to thank Don S. Daly and Kathrin Olson-Rutz for technial assistance, and Curt C. Stroebel for assistance in the field.

Manuscript accepted 24 May 1993. between shoots. When defoliated, rhizome-integrated shoots may be subsidized by other connected shoots, or dormant buds may be stimulated to initiate new shoot growth, as Jónsdóttir and Callaghan (1989) found for Carex bigelowii. This information indicates that beaked sedge may compensate for grazing by increasing tiller density up to some defoliation level, then lose tillers with greater or longer use.

We hypothesized that beaked sedge would compensate for light to moderate grazing by cattle by increasing shoot density. We also wanted to determine the relative contributions of natality and mortality to changes in shoot density.

\section{Materials and Methods}

\section{Site Description}

The study area lies along an upper reach of Cottonwood Creek, a first order stream (Strahler, blue line) in the Montana Agricultural Experiment Station's Red Bluff Research Ranch in southwest Montana. Elevation is about $1,700 \mathrm{~m}$ and the site receives about 480-mm annual precipitation (NOAA 1990). Over 30\% of the average annual precipitation falls in May and June, whereas only about $15 \%$ falls from November through February. Total growing season (April-October) precipitation was $285 \mathrm{~mm}$ in 1989 and 286 $\mathrm{mm}$ in 1990. We classified a soil profile in Stand 1 as a sandy, mixed, frigid Fluvaquentic Haploquoll (Soil Survey Staff 1990) originating from gniess, schist, and amphobolite. This profile description was comparable to that for core samples taken from Stands 2, 3, and 4.

We studied 4 beaked sedge stands in perennial seeps along Cottonwood Creek (Aspie 1989). Pasture sizes were: 0.9 ha in Pastures 1 and 4, 1.3 ha in Pasture 2, and 1.45 ha in Pasture 3. Riparian areas comprised about $30 \%$ and beaked sedge stands about $3 \%$ of the area within the respective pastures. In some areas beaked sedge was virtually monotypic, although we defined "beaked sedge stands" as areas where beaked sedge comprised 50\% or more of the total herbaceous composition. Co-dominant herbaceous species included Nebraska sedge (Carex nebraskensis Dewey), redtop (Agrostis stolonifera L.), and Kentucky bluegrass (Poa pratensis L.). Dominant woody species were quaking aspen (Populus tremuloides Michx.), Bebb willow (Salix bebbiana Sarg.), and yellow willow (Salix lutea Nutt.).

Grazing in the Cottonwood Creek study area was generally light and sporadic prior to the early 1940s, when sheep were introduced. Sheep were replaced by cattle and horses by the 1960s. An experimental grazing system was established in 1980, stocked with Hereford-Angus cross heifers at 6 animal unit months (AUMs)/ha. Two more pastures were added in 1985, stocked with Hereford-Angus cross cow/calf pairs at about 9 AUMs/ha. Marlow and Pogacnik (1986) found that these cow/ calf pairs grazed in the uplands early in the grazing season (June), but concentrated in 
the riparian areas of Cottonwood Creek during late summer and early fall (July-October).

\section{Experimental Design}

We selected 4 beaked sedge stands in 4 padd ocks of an 8 paddock short duration grazing system along Cottonwood Creek in June 1989. Eighty $0.04-\mathrm{m}^{2}$ round plots were distributed among the stands (Fig. 1) and were the replicates for analysis. Forty plots were

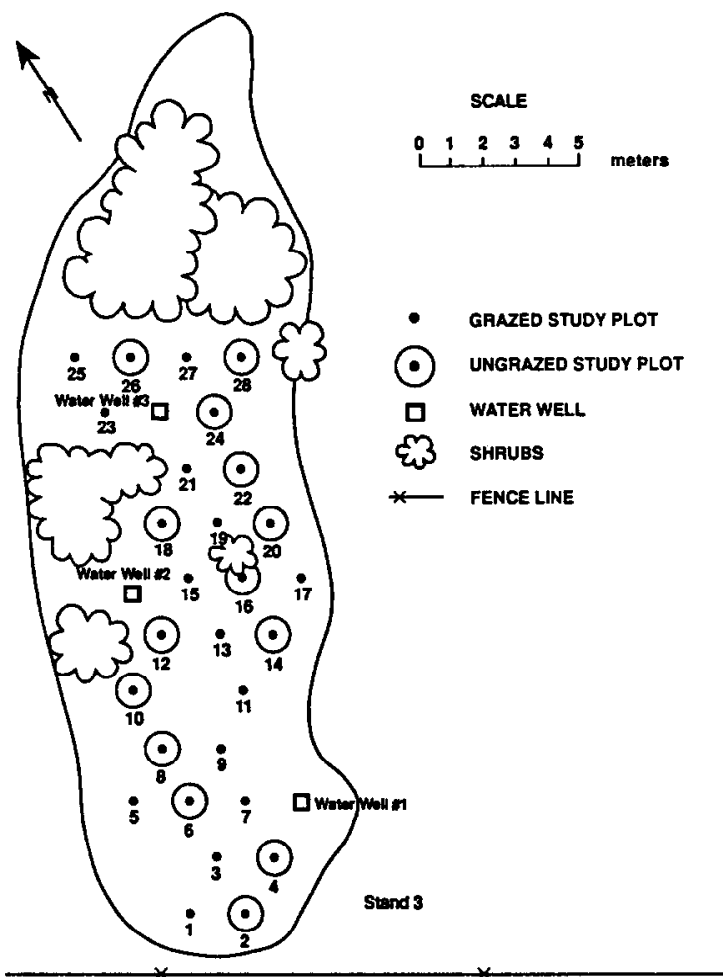

Fig. 1. Schematic diagram of a typical beaked sedge study stand with layout of grazed and ungrazed plots and water wells.

grazed and 40 were protected from grazing by $1.0-\mathrm{m}$ diameter cages. To minimize immigration of shoots, in June 1989 we severed rhizomes in a $1-\mathrm{m}$ diameter circle around each plot to a depth of $30-\mathrm{cm}$. We randomly assigned the treatment of the first plot in each stand, then alternated treatments every $2 \mathrm{~m}$. Stands were grazed in late June and mid-September of 1989 and 1990 by 12 cow/calf pairs. Cows remained in each paddock 1-3 days, until utilization of preferred riparian vegetation, mainly Kentucky bluegrass, reached $60-80 \%$ (visual estimation). This achieved moderate use of the sedge plots without excessive use of adjacent riparian communities.

All existing shoots were marked with red wires in June 1989, and all emerging shoots in subsequent months were marked with wires of different colors. Shoot density, emergence, and mortality were monitored monthly for 2 calendar years, except during winter when covered by snow.

Stand, initial shoot counts, soil penetration resistance, and basal groundcover of competing vegetation were measured and used as covariates in statistical analyses. Penetration resistance of each plot was estimated in September 1989 and 1990 with a Soiltest proving-ring penetrometer. We measured penetration resistance 1.0-m north, south, east, and west of each plot and averaged the 4 measurements. Combined basal groundcover of all species other than beaked sedge was estimated in each plot in September 1989 and 1990.

\section{Statistical Analysis}

We used the SAS Institute, Inc. (1987) General Linear Model (GLM) Repeated Measures procedure for the analysis of variance with covariates for shoot density and shoot emergence for 1989 and 1990. Because the same plots were sampled repeatedly over time, the statistical test of our hypothesis also needed to account for the correlation between monthly observances of the same plots.

We also tested for differences in overall mean shoot density and new shoot emergence, combined over the duration of the study. Because the stand by treatment interaction was not significant, we removed it from the model and calculated the residual sum of squares for the error term in our tests of significance. The shoot emergence data contained many low counts characteristic of Poisson distributions. It is important to note that ANCOVA is not appropriate for counting data which fall into a Poisson-type distribution. ANCOVAs, ANOVAs, and T-tests are based on linear model theory, assuming that errors are independently and identically distributed. When counting data are square-root transformed, the error often approximates a normal distribution, in which case an ANCOVA is acceptable (Sokal and Rohlf 1981). The error distribution of our shoot emergence data approximated a normal distribution when we square-root transformed the data. The mortality data, however, were more variable, with many low counts and occasional large numbers. Because these data did not approach a normal distribution even when using standard transformations, they were summarized graphically without statistical analysis. We used the time by treatment interactions (Gurevitch and Chester 1986) to test our hypotheses of Carex rostrata response to grazing. We determined that beaked sedge did not respond to grazing if the time by treatment interaction was not significant $(P>0.05)$.

We back-transformed (squared) the shoot emergence least square means (LS Means) for graphic display of actual means. We estimated $95 \%$ confidence intervals (CIs) taking into account the heterogeneous variance of monthly counts, which is compatible with Hotelling's T. For emergence data the confidence intervals were calculated using the transformed results, then squared for graphic display.

We compared the difference in mean shoot height (LS Means) between June 1989 and June 1990 by treatment using SAS (1987) GLM procedure for analyses of variance.

\section{Results}

The grazing treatment affected shoot density differently over time (time by treatment interaction $P<0.001$, Fig. 2). Overall mean shoot densities of the grazed and ungrazed plots, however, were not statistically different $(P=0.073)$. Initial mean shoot densities in grazed and ungrazed plots were not statistically different (16.1 and 16.9 shoots per plot, respectively). At the end of 2 years shoot densities were $28.7 \%$ greater in the grazed plots and $11.3 \%$ greater in the ungrazed plots than initial densities. In the statistical model, stand $(P<0.001)$, penetration resistance $(P<0.054)$ and initial shoot count $(P<0.001)$ were important as covariates, but did not interact with the grazing treatments.

To further describe the shoot density profile, we identified maximum contrast coefficients using a multivariate profile analysis (SAS Institute, Inc. 1987). Because this was an a posteriori test, we adjusted for experiment wise Type I error at $P=0.05$ (Sokal and Rohlf 1981). About $90 \%$ of the time by treatment interaction occurred from September 1989 through July 1990. There was no significant interaction during the first 3 nor the last 6 months of the study. Mean shoot density was $11 \%$ greater in the ungrazed plots 


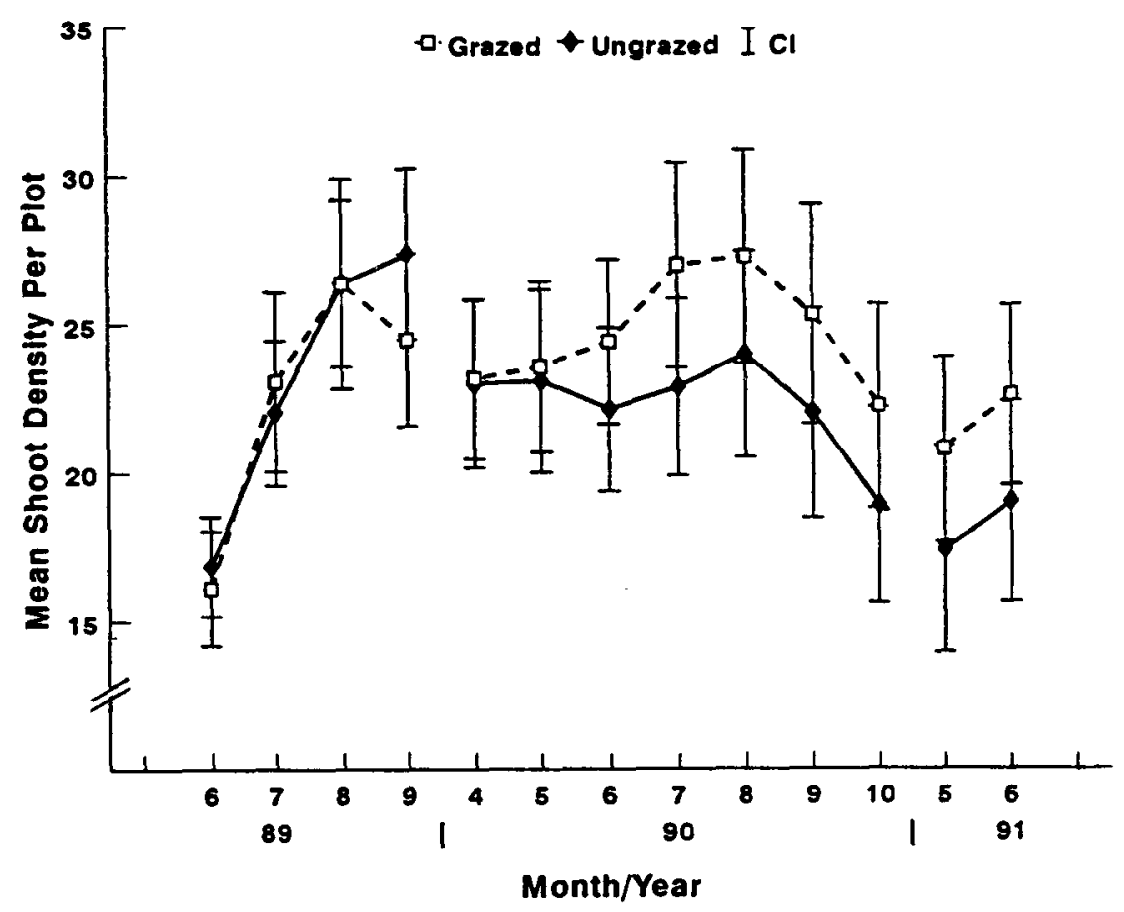

Fig. 2. Profile of mean shoot density per plot by month and year. $95 \%$ Confidence Interval $(\mathrm{CI})=\overline{\boldsymbol{x}}_{\mathbf{t}} \pm \mathbf{t 3 9 , 0 . 0 2 5} * \mathbf{S E}\left(\overline{\boldsymbol{x}}_{t}\right)$.

than the grazed plots in September 1989, but was greater in the grazed plots by June 1990 , rcmaining 12 to $16 \%$ greater in the grazed plots through June 1991.

The effect of our grazing treatments on new shoot production also varied over time (time by treatment interaction $P=0.003$ ). Overall shoot emergence (Fig. 3) was $20 \%$ greater in the grazed plots than the ungrazed plots $(P=0.006)$ during the study. Shoot emergence was greater in the grazed plots than the ungrazed plots in the months following 3 of the 4 grazing treatments. Stand $(P<0.001)$, penetration resistance ( $P=0.003)$, initial shoot count $(P<0.001)$, and competition ( $P=0.09)$ were all important as covariates, but did not interact with the grazing treatments.
Mean overall shoot mortality per plot combined over both years was similar for the grazed and ungrazed plots (29.2 and 28.9, respectively, Table 1). Mortality tended to be greater in the ungrazed plots in the first year of the study, and greater in grazed plots in the second year. An overall average of $33 \%$ of height, or about $15 \%$ of weight (McDougald and Platt 1976) was removed from grazed beaked sed ge plots per grazing treatment, with a range of $0 \%$ to $74 \%$ height removed ( $0 \%$ to $40 \%$ weight removed). Percent height removed was greater in September, when soils were generally drier and more firm, than in June of both 1989 and 1990 (Table 2).

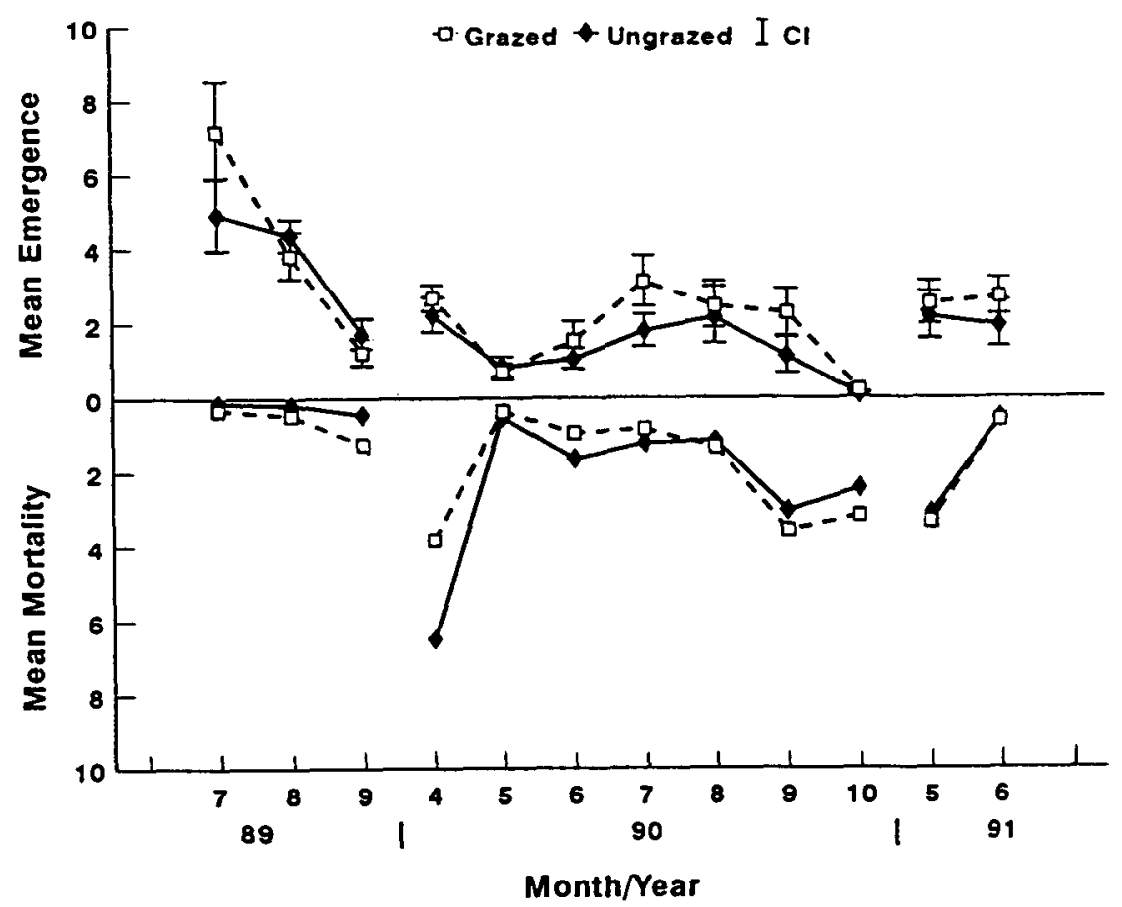

Fig. 3. Profile of mean shoot emergence and mortality per plot by month and year. $95 \%$ Confidence Interval (CI) for shoot emergence $\left[\bar{x}_{\mathrm{t}} \pm \mathrm{t} 39,0.025 *\right.$ $\left.\mathrm{SE}\left(\bar{x}_{\mathrm{t}}\right)\right]^{2}$. 
Table 1. Mean overall shoot mortality per plot during June 1989 through June 1990 through June 1991.

\begin{tabular}{lcccccc}
\hline \hline Treatment & Year 1 & SE & Year 2 & SE & Combined & SE \\
\hline & $(\%)$ & & $(\%)$ & & $(\%)$ & \\
Grazed & 11.0 & 1.0 & 18.2 & 1.4 & 29.2 & 1.8 \\
Ungrazed & 13.0 & 1.0 & 15.9 & 1.0 & 28.9 & 1.6 \\
Combined & 12.0 & 0.7 & 17.0 & 0.8 & 29.0 & 1.2 \\
\hline
\end{tabular}

SE-Standard Error

Table 2. Mean percent height removed per grazed plot for 1989 and 1990.

\begin{tabular}{|c|c|c|c|c|c|c|c|c|}
\hline \multirow[b]{2}{*}{ Stand } & \multicolumn{4}{|c|}{1989} & \multicolumn{4}{|c|}{1990} \\
\hline & June & SE & Sept & $\mathrm{SE}$ & June & SE & Sept & $\mathrm{SE}$ \\
\hline & $(\%)$ & & $(\%)$ & & $(\%)$ & & $(\%)$ & \\
\hline 1 & 14.2 & 8.4 & 36.9 & 25.2 & 37.8 & 11.6 & 35.2 & 11.6 \\
\hline 2 & 29.3 & 21.2 & 48.3 & 11.4 & 23.5 & 16.1 & 39.3 & 12.0 \\
\hline 3 & 4.9 & 10.1 & 49.7 & 14.9 & 26.0 & 19.8 & 34.2 & 14.5 \\
\hline 4 & 15.9 & 15.5 & 34.7 & 20.3 & 20.5 & 17.6 & 53.4 & 15.2 \\
\hline Combined & 15.2 & 17.2 & 43.6 & 17.9 & 25.3 & 17.8 & 40.9 & 15.5 \\
\hline
\end{tabular}

SE Standard Error

Although rodent grazing of beaked sedge shoots increased in spring 1990, particularly in the ungrazed plots, rodent-caused shoot deaths in the grazed and ungrazed plots was about 7 and $13 \%$, respectively, of overall mortality. Primary rodent grazers were meadow voles (Microtus pennsylvanicus Wagner) and deer mice (Peromyscus maniculatus Ord). Rodents cut shoot bases cleanly at ground level, whereas cattle rarely clipped shoots shorter than $10 \mathrm{~cm}$.

Mean shoot heights (measured to tip of longest green material) of grazed and ungrazed plots declined 6 and $5 \%$, respectively, from June 1989 to June 1990. The change in mean shoot height was similar between treatments (Table 3).

Table 3. Mean differene in mean shoot heights $(\mathrm{cm})$ between grazed and ungrazed plots measured in June 1989 and June 1990.

\begin{tabular}{|c|c|c|c|c|}
\hline Stand & Grazed & SE & Ungrazed & SE \\
\hline & (cm) & & $(\mathrm{cm})$ & \\
\hline $\begin{array}{c}\text { Mean height } \\
\text { June } 89\end{array}$ & 52.6 & 0.6 & 50.6 & 0.6 \\
\hline $\begin{array}{c}\text { Mean height } \\
\text { June } 90\end{array}$ & 49.3 & 0.5 & 48.1 & 0.6 \\
\hline $\begin{array}{l}\text { Mean height } \\
\text { June } 89 \text {-June } 90\end{array}$ & $-3.3^{a}$ & 1.5 & $-2.5^{\mathrm{a}}$ & 1.5 \\
\hline
\end{tabular}

Shoot density and shoot emergence tended to be greater in stand 1 than in stands 2,3 , and 4, and in plots with high initial shoot counts. Although penetration resistance and competition were significant as covariates, there was no clear association of these covariates with shoot density or shoot emergence. Mean penetration resistance index tended to be greatest in Stands 2 and 3, less in Stand 1, and least in Stand 4 (Table 4). Soil penetration resistance corresponded roughly with soil moisture. Saturated soils were least resistant and drier soils most resistant to penetration. Overall penetration resistance was least in September 1989, greater in June 1990, and greatest in September 1990. Water wells monitored during this period indicated steadily dropping water levels in all stands during the 2-year study.

Percent cover of competing species was less than $30 \%$ in 66 of 80 sample plots (Table 5). Shoot density and emergence of beaked
Table 4. Mean penetration resistance index (top $30 \mathrm{~cm}$ ) estimated at each study plot on 3 different dates.

\begin{tabular}{cccc}
\hline \hline Stand & Sept 89 & June 90 & Sept 90 \\
\hline 1 & 11.6 & 15.1 & 22.7 \\
2 & 18.2 & 21.8 & 32.7 \\
3 & 16.4 & 22.5 & 24.8 \\
4 & 10.6 & 14.8 & 15.9 \\
Combined & 14.7 & 19.3 & 24.1 \\
\hline
\end{tabular}

Table 5. Percent of Carex plots containing various basal cover classes of competing species.

\begin{tabular}{|c|c|c|c|c|}
\hline Stand & $<5 \%$ & $5-30 \%$ & $30-50 \%$ & $>50 \%$ \\
\hline & \multicolumn{4}{|c|}{$\ldots \ldots(\%) \ldots \ldots$} \\
\hline 1 & 60 & 40 & 0 & 0 \\
\hline 2 & 50 & 25 & 25 & $\mathbf{0}$ \\
\hline 3 & 39 & 43 & 11 & 7 \\
\hline 4 & 36 & 46 & 9 & 9 \\
\hline Overall & 44 & 39 & 12 & 5 \\
\hline
\end{tabular}

sedge tended to be greater in plots with less competition from other species. Competition appeared to be affected by water level and accessibility to livestock. Competition was light in soils inundated ycar-round, and greater in moist but aerobic soils. Soils disturbed by hoof action provided conditions favorable to the establishment of annual and perennial dicots.

\section{Discussion}

\section{Shoot Population Response}

Because mean shoot density changed differently in grazed plots compared with ungrazed plots over time, particularly in fall 1989 and spring 1990, we rejected the null hypothesis that light to moderate cattle grazing has no effect on shoot density.

In September 1989 shoot density was greater in the ungrazed plots than the grazed plots, which was unexpected. We observed greater trampling impacts in September 1989 when use averaged about $43 \%$ (height removed), than in June 1989, when use averaged about $15 \%$. Shoot mortality in September 1989 was $57 \%$ greater in the grazed than in the ungrazed plots ( 1.90 and 0.82 shoots per plot, respectively), while shoot emergence was $22 \%$ lower in the grazed than in the ungrazed plots ( 1.70 and 2.18 shoots per plot, respectively). Due to cool temperatures and drier soil conditions, there may have been a lag in the response of the grazed plants to September grazing. The lag in shoot emergence combined with greater shoot mortality due to grazing and trampling could explain lower shoot density in the grazed plots in September 1989, although this result was not repeated in 1990 . Shoot density increased more in the grazed plots than the ungrazed plots in spring 1990 , and remained 12 to $16 \%$ greater through spring 1991. This result may indicate that shoot density was adjusting to our treatment through the first year, then reached equilibrium in the second year.

Peak shoot density occurred in September of both years, which is slightly later than Hultgren's (1988) finding of mid-summer peak shoot density. Shoot density ranged from about 400 to $680 \mathrm{~m}^{-2}$ in our stands. This is high compared with most recent studies (Table 6), but similar to densities reported by Mörnsjö (1969). Shoot density fluctuated by about $40 \%$ (maximum density minus minimum density divided by maximum density) in the grazed plots and $38 \%$ in the ungrazed plots. These results support Hultgren's (1988) findings that shoot density fluctuated by about $54 \%$ over a 4 -year 
Table 6. Shoot densities of beaked sedge reported from the northern hemisphere.

\begin{tabular}{lcc}
\hline \hline Author & Location of study & Density \\
\hline Mörnsö (1969) & Sweden & $\left(\right.$ Shoots $\left.{ }^{-2}\right)$ \\
Gorham and Somers & Alberta & 370 \\
$\quad(1973)$ & Minnesota & 238 \\
Bernard (1974) & New York & 264 \\
Bernard and & & \\
$\quad$ Hankinson (1979) & Sweden & $128-476$ \\
Hultgren (1988) & Montana & $400-684$ \\
Allen and Marlow (1992) & & \\
\hline
\end{tabular}

period. Bernard and Gorham (1978) report a fluctuation of $24 \%$ over a single year.

Because mean shoot emergence responded differently over time with grazing (time by treatment interaction $P=0.003$ ), we rejected the null hypothesis that cattle grazing had no effect on shoot emergence. The greatest differences in emergence between grazed and ungrazed treatments occurred in July 1989, July 1990, and September 1990 . The July shoot counts followed the June grazing treatments by 4 to 5 weeks, whereas the September counts followed the September grazing treatments by about 2 weeks. We concluded that beaked sedge in grazed plots compensated for shoot defoliation by increasing new shoot production up to 5 weeks following grazing treatments.

Peak shoot emergence was concentrated in June through August in both treatments, which supports Hultgren's (1988) findings of peak emergence in late spring-early summer. Relative differences in shoot emergence between grazed and ungrazed plots were greatest during the comparatively rapid growth period of late June-early July, although lower use of the grazed plots in June than in September of both years may have affected this result.

Grant et al. (1981) reported increased rates of new leaf and tiller production in clipped plots of perennial ryegrass (I olium perenne L.). New leaf and tiller production was greatest during the first and second weeks of the regrowth period, diminishing after 3 to 4 weeks. Increased shoot emergence in our study in July 1989 and 1990 and in September 1990 appears to have been due more to grazing treatments than an effect of season.

\section{Shoot Mortality}

Shoot mortality was greatest during winter and late summer (Fig. 3), which agrees with the findings of Gorham and Somers (1973). Shoot mortality was greater in the ungrazed plots in April through July 1990 . Rodent-caused shoot mortality was greatest in the ungrazed plots during the same period.

Rodents cut shoots into small segments to access inflorescences for food (Getz 1985), or removed stem bases or root crowns. To minimize this influence we removed rodents from the stands in June 1990 using Sherman live traps. The greater use of ungrazed plots by rodents in our study is explained by the attraction of both meadow voles and deer mice to greater vegetative cover (Birney et al. 1976, Getz 1985) afforded by utilization cages.

Shoot mortality generally peaked later than shoot emergence. This supports the conclusions of Noble et al. (1979) and Cook (1985) that increased shoot mortality of clonal plants follows increased emergence due to source-sink relationships of integrated root systems and increased competition. Shoot mortality was generally lower in summer 1989 than in summer 1990, as was shoot density. Greater mortality may have been a density dependent response, or may have been due to lower 1990 water levels. Although density undoubtedly affected relative rates of natality and mortality, precipitation, and temperature may have been more important influences (Hultgren 1988) on shoot flux in our study.

\section{Management Implications}

These data indicate that the basic tenets of plant grazing tolerance drawn from rhizomatous upland graminoids generally apply to beaked sedge. Therefore, with adequate time for regrowth, beaked sedge should tolerate light to moderate, early summer and fall grazing in southwestern Montana.

Because we studied the response of beaked sedge to light or moderate grazing with at least 60 days rest to provide the full opportunity to produce new photosynthetically active tissue, other grazing intensities and frequencies might produce different results. By testing different combinations of grazing frequency and intensity, we may be able to determine compensatory response thresholds.

Deferring grazing of beaked sedge stands in wet years until fall when soils are less susceptible to trampling (Marlow et al. 1987) should minimize stream bank instability and soil displacement in seeps. Grazing beaked sedge earlier and heavier in dry years may optimize shoot natality. Long-term monitoring programs are needed to determine whether cumulative effects from defoliation and soil displacement by trampling are severe enough to limit the survival of local beaked sedge populations.

\section{Literature Cited}

Aspie, J.M. 1989. Influence of groundwater on streambank- soil-moisture content, storm-runoff production, and sediment production in a semiarid watershed, southwest Montana. MS Thesis, Montana State Univ., Bozeman.

Bernard, J.M. 1974. Seasonal changes in standing crop and primary production in a sedge wetland and an adjacent dry old-field in central Minnesota. Ecology 55:350-359.

Bernard, J.M., and E. Gorham. 1978. Life history aspects of primary production in sedge wetlands, p. 39-51. In: Ralph E. Good (ed.). Freshwater wetlands: Ecological processes and management potential. Academic Press, N.Y.

Birney, E.C., W.E. Grant, and D.D. Baird. 1976. Importance of vegetative cover to cycles of Microtus populations. Ecology 57:1043-1051.

Carlsson, B.A., and T.V. Callahan. 1990. Programmed tiller differentation, intraclonal density regulation and nutrient dynamics in Carex bigelowii. Oikos 58:219-230.

Cook, R.E. 1985. Growth and development in clonal plant populations, p. 259-298. In: J.B.C. Jackson, L.W. Buss, and R.E. Cook (eds.). Population biology and evolution of clonal organisms. Yale Univ. Press. New Haven, Conn.

Getz, L.L., 1985. Habitats, p. 286-309. In: Biology of new world Microtus. R.H. Tamarin (ed.), Amer. Soc. Mammal.

Gorham, E., and M.G. Somers. 1973. Seasonal changes in the standing crop of two montane sedges. Can. J. Bot. 51:1097-1108.

Grant, S.A., G.T. Barthram, and L. Torvell. 1981. Components of regrowth in grazed and cut Lolium perenne swards. Grass and Forage Sci. 36:155-168.

Gurevitch, J., and S.T. Chester, Jr. 1986. Analysis of repeated measures experiments. Ecology 67:251-255.

Hansen, P.L., S.W. Chadde, and R.D. Pfister. 1988. Riparian dominance types of Montana. Montana Riparian Assoc. School of Forestry. Missoula.

Hermann, F.J. 1970. Manual of the carices of the Rocky Mountains and Colorado Basin. Agricultural Handbook No. 374. USDA Forest Service. U.S. Gov. Print. Off., Washington, D.C.

Hultgren, A.B.C. 1988. A demographic study of aerial shoots of Carex rostrata in relation to water level. Aquatic Bot. 30:81-93.

Kovalchik, B.L. 1987. Riparian zone associations: Deschutes, Ochoco, Fremont, and Winema National Forests. USDA Forest Service Pub. R6 Ecol TP-279-87. Pacific Northwest Region. Bend, Ore.

McDougald, N.K. and R.C. Platt. 1976. A method of determining utilization for wet mountain meadows on the Summit Allotment, Sequoia National Forest, California. J. Range Manage. 29:497-501.

Marlow, C.B., and T.M. Pogacnik. 1986. Cattle feeding and resting patterns in a foothills riparian zone. J. Range Manage. 39:212-217.

Marlow, C.B., T.M. Pogacnik, and S.D. Quinsey. 1987. Streambank stability and cattle grazing in southwestern Montana. J. Soil Water Cons. 42:291-296. 
Maschinski, J. and T.G. Whitham. 1989. The continuum of plant responses to herbivory: The influence of plant association, nutrient availability, and timing. Amer. Natur. 134:1-19.

Mörnsjö, T. 1969. Studies on vegetation and development of a peatland in Scania, South Sweden. Opera Bot. No. 24.

National Oceanic and Atmospheric Administration (NOAA). 1989-1991. Climatological Data, Montana. Vols. 91-94. National Climatic Data Center. Ashville, N.C.

Noble, J.C., A.D. Bell, and J.L. Harper. 1979. The structural demography of rhizomatous plants: Carex arenaria L. I. the morphology and flux of modular growth units. J. Ecol. 67:983-1008.

Ratliff, R.D. 1983. Nebraska sedge (Carex nebraskensis Dewey): observations on shoot life history and management. J. Range Manage. $36: 429-430$
SAS Institute, Inc. 1987. User's guide: Statistics, version 5 edition. Cary, N.C.

Soil Survey Staff. 1990. Keys to soil taxonomy, 4th ed. SMSS Tech. Monog. 6. Blacksburg, $\mathrm{Va}$.

Sokal, R.R., and F.J. Rohlf. 1981. Biometry. 2nd ed. W.H. Freeman and Company. N.Y.

Tiner, R.W. Jr. 1984. Wetlands of the United States: current status and recent trends. USDI Fish and Wildlife Serv. U.S. Gov. Print. Off. Washington, D.C.

U.S. General Accounting Office. 1988. Public rangelands: some riparian areas restored but widespread improvement will be slow. GAO/RCED88-105. Washington, D.C. 